\title{
PENGEMBANGAN KOMIK IPA BERBASIS KARAKTER PEDULI LINGKUNGAN PADA MATERI STRUKTUR DAN FUNGSI BAGIAN TUMBUHAN (Uji Coba Siswa Kelas IV SD Muhammadiyah Kleco)
}

\author{
Arum Syafrilia Trisnaningsih \\ Ika Maryani \\ PGSD FKIP Universitas Ahmad Dahlan \\ arumsyafrilia@gmail.com
}

\begin{abstract}
This study aims to: 1) know the development steps of IPA based on environmental character concerns on the structure and function of the pupil part IV grade elementary school, 2) to know the feasibility of science-based character-based IPA character on the material structure and function of plant part IV fourth grade. This research is a research development (Research and Development) using a model used by Robert Maribe Brance is the development of ADDIE. The subject of this research is the fourth grader of SD Muhammadiyah Kleco Kotagede Yogyakarta. Data collection techniques on product trials using teacher and student assessment questionnaires.

The results showed that the assessment of media experts get the value of 83.3 with the category of "very decent". Expert assessment of the material score of 87.5 with the category "very feasible". Assessment of learning experts get the value of 95.8 with the category "very feasible". The conclusion from the researchers that the media has been feasible and effective use as a medium of learning for teachers and students of grade IV primary school.
\end{abstract}

Keywords: Comics, Character of environmental care, material structure and function of plant part, science elementary school.

\begin{abstract}
ABSTRAK
Penelitian ini bertujuan untuk: 1) mengetahui langkah pengembangan Komik IPA berbasis karakter peduli lingkungan pada materi struktur dan fungsi bagian tubuhan siswa kelas IV SD, 2) mengetahui kelayakan Komik IPA berbasis karakter peduli lingkungan pada materi struktur dan fungsi bagian tumbuhan siswa kelas IV SD. Penelitian ini adalah penelitian pengembangan (Research And Development) menggunakan model yang digunakan menurut Robert Maribe Brance yaitu pengembangan ADDIE. Subjek uji coba dalam penelitian ini adalah siswa kelas IV SD Muhammadiyah Kleco Kotagede Yogyakarta. Teknik pengumpulan data pada uji coba produk menggunakan angket penilaian guru dan siswa,

Hasil penelitian menunjukan bahwa penilaian ahli media mendapatkan nilai 83,3 dengan kategori "sangat layak". Penilaian ahli materi mendapatkan nilai 87,5 dengan kategori "sangat layak". Penilaian ahli pembelajara mendapatkan nilai 95,8 dengan kategori "sangat layak". Kesimpulan dari peneliti bahwa media telah layak dan efektif digunakan sebagai media pembelajaran bagi guru dan siswa kelas IV sekolah dasar.
\end{abstract}


Keywords: Komik, Berkarakter peduli lingkungan, materi struktur dan fungsi bagian tumbuhan, IPA Sekolah Dasar.

\section{PENDAHULUAN}

Bumi merupakan tempat hidup manusia. Bumi sekarang sudah tidak senyaman dahulu lagi. Bumi mengalami kerusakan yang diakibatkan oleh aktivitas yang dilakukan manusia itu sendiri. Kini manusia berbondong-bondong untuk menjaga kelestarian dan mengembalikan bumi agar seperti dahulu kembali. Berbagai macam cara dilakukan manusia agar bumi dapat asri dan nyaman kembali. Di kalangan masyarakat saat ini bersama-sama sedang digerakkan sikap peduli lingkungan melalui berbagai macam kegiatan yang mendukung, mulai dari hal yang terkecil yaitu membuang sampah pada tempatnya (Martani, 2011).

Bentuk-bentuk kepedulian dan kesadaran di lingkungan sudah mulai tampak. Hal ini terlihat dari kebijakan-kebijakan yang dikeluarkan oleh pemerintah maupun kegiatan yang dilakukan oleh masyarakat. Kebijakan pemerintah yang dimaksud seperti gerakan sejuta pohon, peringatan hari bumi, maraknya kegiatan daur ulang sampah dan kertas, serta maraknya Lembaga Swadaya Masyarakat yang memberikan perhatian terhadap lingkungan hidup. Upaya tersebut menunjukan adanya peningkatan kepedulian lingkungan di kalangan masyarakat dan pemerintah Indonesia (Martani, 2011).

Konferensi PBB tentang lingkungan hidup di Stockhlom, Swedia, pada tanggal 15 juni 1972 diadakan karena dunia mencemaskan akan kerusakan lingkungan (Salim, 2012). Kurangnya rasa peduli lingkungan mengakibatkan terjadinya eksploitasi dan kerusakan lingkungan. Untuk mengatasi hal tersebut, salah satunya dengan upaya menanamkan dan mengenalkan rasa peduli lingkungan melalui jalur pendidikan, tidak terkecuali pendidikan sekolah dasar. Menurut Himpunan Peduli Lingkungan Indonesia (HPLI) menyatakan bahwa anak-anak lebih mudah diajak untuk peduli lingkungan daripada orang dewasa. Anak kecil apabila dibiasakan untuk cinta lingkungan sejak dini, maka ini akan berlanjut sampai mereka dewasa.

Gerakan lingkungan yang dicanangkan oleh pemerintah dan telah tersebar ke seluruh lapisan masyarakat. Lingkungan pendidikan seharusnya menjadi fokus utama yang penting pada program lingkungan. Hal tersebut karena dalam lingkungan pendidikan terdapat generasi-generasi penerus, sehingga perlu ditanamkan perilaku peduli lingkungan di lingkungan sekolah sejak dini. Di sekolah dasar ada berbagai macam mata pelajaran yang diajarkan. Salah satu mata pelajaran yang dapat menumbuhkan karakter peduli lingkungan yaitu mata pelajaran Ilmu Pengetahuan Alam. IPA merupakan mata pelajaran yang paling dekat dengan lingkungan.

Pembelajaranya sangat dikaitkan dengan lingkungan yang ada di sekitarya siswa diajak untuk lebih menyayangi, mencintai dan merawat lingkungan yang ada di sekitar. Pembelajaran IPA memiliki peranan sangat penting dalam pengembangan karakter siswa. Sebagai penerus bangsa, siswa juga harus memiliki etika dan moral yang baik. Menurut Zuchdi (2011) pendidikan sains berperan dalam tiga unsur karakter (moral knowing, moral feeling, and moral action) sebagai tiga aspek kepribadian manusia, yaitu dengan mengetahui perbuatan ma'ruf dan terbiasa berpikir, berhati, dan bertindak ma'ruf. Pengembangan Karakter melalui sains ini memerlukan pembiasaan sikap, keteladanan, dan tindakan di lingkungan sehingga berkarakter tinggi dan kuat.

Ilmu Pengetahuan Alam di dalamnya membahas mengenai alam beserta isinya (Wisudawati, 2014). Melalui pembelajaran IPA diharapkan peserta didik dapat memahami tentang menjaga lingkungan alam dan mampu memcahkan permasalahan atau menerapkan suatu konsep pada IPA yang tentunya sangat 
berkaitan erat dengan lingkungan sekitar.

Pembelajaran IPA merupakan pembelajaran yang menyenangkan karena berhubungan langsung dengan alam sekitar. Ilmu Pengetahuan Alam (IPA) merupakan mata pelajaran yang berhubungan dengan mencari tahu. Jadi pembelajaran IPA bukan hanya sekedar fakta-fakta, konsep-konsep, prinsip-prinsip, namun juga sebuah proses penemuan. Pembelajaran IPA menekankan pada penemuan langsung. Melalui pengalaman langsung siswa akan lebih memahami apa yang mereka pelajari. Siswa akan lebih terlatih untuk dapat menemukan berbagai pengetahuan sehingga pembelajaran akan menjadi lebih aktif. Siswa diberikan pengalaman dan kesempatan langsung mengenai fakta, konsep, dan prinsip. Dengan demikian, pembelajaran akan lebih mengena pada siswa dalam kehidupan sehari-hari (Mulyasa, 2012).

Pada siswa kelas IV siswa memang tertarik pada hal-hal yang bersifat langsung, karena pada dasarnya anak kelas IV (kelas tinggi) masih senang dengan bermain. Perkembangan kognitif siswa terbagi menjadi sensormotor (umur 0-2 tahun), praoperasional (2-7) tahun, operasional konkret (7-12 tahun), dan tahap operasional formal (7-12 tahun). Berdasarkan perkembangan kognitif anak, siswa kelas IV SD rata-rata berumur 9-10 tahun atau masa praoperasional konkret. Pada usia ini anak sudah mulai menggunakan pemikiranya pada benda-benda dan kejadian akrab dan siswa cenderung akan lebih tertarik pada pembelajaran yang dilakukan secara langsung (Budiningsih, 2012).

Pembelajaran akan lebih aktif apabila memaksimalkan fasilitas yang ada di sekolah. Ada berbagai metode, teknik, dan media yang dapat digunakan agar pembelajaran sesuai dengan yang diharapkan. Salah satunya alternatif yang dapat dilakukan agar pembelajaran dapat maksimal yaitu dengan menggunakan media pembelajaran. Hamalik (2013) berpendapat bahwa media pendidikan adalah alat, metode, teknik yang dapat digunakan dalam rangka lebih mengkomunikasikan interaksi antara guru dan siswa dalam proses pendidikan dan pengajaran di kelas. Media digunakan sebagai salah satu sarana untuk meningkatkan mutu pendidikan, media sangat penting penggunaanya karena dapat membantu siswa dalam proses belajar dan dapat mempertinggi hasil belajar.

Berdasarkan hasil observasi di SD Muhammadiyah Kleco ketika Magang Dasar, Lanjut, dan Terapan pada bulan Februari, Maret, dan Agustus tahun 2016 pada saat pembelajaran IPA menunjukan minat siswa terhadap pelajaran masih kurang. Hal ini dibuktikan pada saat pembelajaran berlangsung siswa cenderung ramai sendiri dan tidak memperhatikan penjelasan dari guru. Tidak sedikit pula siswa yang dan bercerita kemudian asyik bermain sendiri dengan temannya. Siswa ketika diberikan pertanyaan oleh guru tidak segera merespon dan menjawab pertanyaan yang guru ajukan. Ketika ada hal-hal yang belum mereka pahami, siswa juga enggan bertanya dengan guru.

Siswa masih mengalami kesulitan dalam pembelajaran IPA di kelas. Penjelasan dari guru kurang diserap dengan maksimal. Hal ini ditunjukkan dengan masih sulitnya siswa untuk memahami beberapa konsep yang abstrak, kemudian banyak istilah-istilah yang baru bagi siswa. Pada saat pembelajaran siswa jarang bertanya kepada guru mengenai gambaran yang masih abstrak, sehingga siswa kurang memahami mengenai gambaran tersebut. Pada saat pembelajaran guru hanya menyampaikan materi di kelas. Pembelajaranya masih konvensional, hanya terbatas pada penyampaian antara guru dan siswa tanpa adanya kegiatan nyata agar siswa memahami materi tersebut. Oleh karena itu, ketika ada suatu konsep atau gambaran yang baru, siswa merasa sulit menangkap dan memahami materi tersebut dengan baik.

Pembelajaran IPA di dalam kelas masih terfokus pada penguasaan materi (IPA sebagai produk), sedangkan IPA sebagai proses dan sikap belum diutamakan. Pemahaman siswa sangat bervariasi karena di dalam kelas terdapat berbagai siswa yang memiliki 
karakteristik yang berbeda. Ada siswa yang begitu mudah menerima materi yang disampaikan guru dan ada yang kurang dalam menerima materi yang disampaikan oleh guru. Hal ini disebabkan berbagai faktor, diantaranya kurang bervariasinya media yang digunakan dalam menunjang kegiatan belajar mengajar di kelas. Kepedulian siswa terhadap lingkungan juga belum nampak, dengan demikian perlu integrasi penanaman nilai cinta lingkungan pada materi pelajaran.

Menurut hasil wawancara pada tanggal 2 Maret 2016 dengan siswa di SD Muhammadiyah Kleco beberapa siswa berpendapat bahwa lingkungan tidak perlu dirawat karena sudah ada yang mengatur dan mengurusnya sendiri. Hanya sedikit siswa yang mengatakan lingkungan harus dijaga dan dilestarikan. Sikap peduli lingkungan pada siswa harus ditanamkan sejak dini mungkin, karena kita juga berkehidupan di lingkungan, melakukan aktivitas di lingkungan, memanfaatkan lingkungan, dan bergantung pada lingkungan sehingga lingkungan harus dijaga kelestariannya.

Bahan ajar SD Muhammadiyah Kleco disajikan berupa lembar kerja siswa. Kemudian siswa mengalami kesulitan untuk menjawab soal di lembar kerja siswa tersebut, karena materi yang disajikan di dalamnya kurang disajikan secara lengkap. Masih rendahnya pemahaman siswa kelas IV SD Muhammadiyah Kleco terhadap konsep IPA berhubungan dengan proses pembelajaran yang belum memberikan peluang bagi siswa untuk mengembangkan kemampuan berpikir kritis, pola pengajaran masih menggunakan pembelajaran konvensional termasuk pemilihan media pembelajaran yang kurang sesuai dengan karakteristik siswa. Oleh karnea itu peneliti menggunakan salah satu media yang menarik dan dapat membantu peserta didik dalam pembelajaran adalah komik.

Media komik merupakan salah satu bentuk sumber belajar yang dapat digunakan secara mandiri oleh siswa dan dapat digunakan oleh guru sebagai alternatif untuk dapat menunjang pembelajaran di kelas. Komik sebagai bentuk kartun yang mengungkapkan karakter dan menerapkan suatu cerita dalam urutan yang erat dan hubunganya dengan gambar yang dirancang untuk memberikan hiburan kepada para pembaca (Daryanto, 2012). Komik pembelajaran memberikan penyajian yang mengandung unsur visual dan cerita yang kuat. Ekspresi yang divisualisasikan membuat pembaca terlibat secara emosional dan membuat pembaca ingin terus membacanya hingga cerita selesai.

Pemilihan komik sebagai media pembelajaran karena terdapat kecenderungan banyak siswa yang menyenangi bacaan media hiburan seperti komik dibandingkan untuk membaca bacaan pelajaran atau mengerjakan tugas. Riva'i (2002) berpendapat bahwa media komik dalam proses belajar menciptakan minat para peserta didik, mengefektifkan proses belajar mengajar, dapat meningkatkan minat belajar dan menimbulkan minat apresiasinya. Dengan demikian, media ini akan dapat memberikan pengaruh dalam hasil belajar siswa, karena dapat menarik perhatian dan minat, memperjelas ide serta sederhana dalam penyampaian informasi.

Komik yang dikembangkan adalah Komik IPA berbasis karakter peduli lingkungan. Menurut Aunillah (2011) Pendidikan karakter merupakan sebuah sistem yang menanamkan nilai-nilai karakter pada peserta didik, yang mengandung komponen pengetahuan, kesadaran individu, tekad, serta adanya kemauan dan tindakan untuk melaksanakan nilai-nilai, baik terhadap Tuhan Yang Maha Esa, diri sendiri, sesama manusia, lingkungan, maupun bangsa sehingga akan terwujud insan kamil. Dengan pembelajaran menggunakan komik berkarakter ini, secara tidak langsung siswa akan mendapatkan materi pelajaran, sekaligus menumbuhkan karakter peduli lingkungan.

Karakter peduli lingkungan pada komik IPA yang akan dikembangkan ini bertujuan agar siswa memiliki karakter peduli lingkungan dalam aplikasi kehidupan sehari-hari, sekolah maupun di masyarakat. Dengan menggunakan komik IPA berkarakter peduli 
lingkungan ini diharapkan dapat tertanam sikap peduli lingkungan siswa, terutama lingkungan yang ada di sekitarnya. Sehingga dengan menggunakan komik dapat dijadikan sebagai media pembelajaran yang sangat menarik dengan isi di dalamnya mengandung konten pelajaran.

Materi pelajaran yang digunakan dalam penelitian ini adalah struktur dan fungsi bagian tumbuhan. Menurut hasil wawancara kepada siswa pada tanggal 3 Maret 2016 bahwa materi struktur dan fungsi bagian tumbuhan dianggap sulit oleh siswa. Oleh karena itu, materi struktur dan fungsi bagian-bagian tumbuhan ini akan lebih mudah dimengerti siswa jika divisualisasikan, salah satunya dengan menggunakan komik berbasis karakter peduli lingkungan.

Menurut penelitian Marzuki (2011), bahwa salah satu hal yang penting yang perlu diperhatikan dalam rangka pembinaan karakter yang efektif di sekolah adalah pelibatan semua mata pelajaran dan semua guru. Pengintegrasian karakter dalam setiap mata pelajaran perlu dilakukan, sebab pendidikan karakter yang diterapkan dalam lingkungan pendidikan akan memiliki dampak langsung pada prestasi belajar. Menurut penelitian Juhartutik (2011), salah satu kriteria paling objektif keberhasilan pendidikan karakter adalah prestasi akademis peserta didik. Berdasarkan hal tersebut komik berkarakter peduli lingkungan merupakan bahan ajar yang dibutuhkan peserta didik. Melihat pentingnya komik IPA berbasis karakter peduli lingkungan pada materi struktur dan fungsi bagianbagian tumbuhan, peneliti berharap dapat mengembangkan komik yang sesuai dengan kurikulum yang berlaku. Komik ini diharapkan dapat menjadi salah satu sumber rujukan dalam proses belajar mengajar di sekolah dasar. Oleh karena itu, penelitian ini diberi judul "Pengembangan Komik IPA Berbasis Karakter Peduli Lingkungan Pada Materi Struktur dan Fungsi Bagian-bagian Tumbuhan Siswa Kelas IV Sekolah Dasar

\section{METODE PENELITIAN}

Model pengembangan dalam penelitian ini mengacu pada pengembangan menurut Robert Maribe Branch (Sugiyono, 2015) langkah-langkah pengembangan ADDIE terdiri dari 5 tahapan diantaranya yaitu Analisis, Design, Development, Implementation, and Evaluation. Pada uji coba awal dilakukan pakar ahli yang diujikan kepada tiga ahli yaitu ahli materi, ahli media, dan ahli pembelajaran untuk mengetahui kekurangan dan kelebihan suatu produk, kemudian dilanjutkan dengan ujicoba kelompok kecil dan ujicoba kelompok besar. Instrumen dalam penelitian ini dalam mengumpulkan data menggunakan angket, observasi dan dokumentasi. Teknis analisis data yang digunakan untuk mengolah data yang diperoleh dalam pengembangan komik IPA berbasis karakter peduli lingkungan pada materi struktur dan fungsi bagian tumbuhan ini adalah dengan menggunakan analisis deskriptif kualitatif dan deskriptif kuantitatif.

Deskriptif kualitatif yaitu dilakukan dengan menggunakan analisis dengan mengelompokan informasi data kualitatif berupa tanggapan, masukan, serta saran dari uji ahli dan saran atau komentar yang diperoleh dari guru dan siswa. Kemudian selanjutnya hasil analisis ini dijadikan pertimbangan dalam melakukan revisi produk. Analisis data kuantitatif dilakukan dengan analisis deskriptif kuantitatif, menganalisis data kuantitatif yang diperoleh dari validasi oleh ahli, penilaian guru, dan angket respon siswa (skala kecil). Skala yang dikembangkan mengacu pada alternative yang dikembangkan oleh (Sugiyono, 2015). 
Tabel 1. Pedoman Penilaian

Jawaban yang dipilih Skala penilaian

\begin{tabular}{cl}
\hline Sangat baik & 4 \\
\hline Layak & 3 \\
\hline Kurang baik & 2 \\
\hline Tidak baik & 1
\end{tabular}

Pada penelitian ini, skala penilaian secara lebih rinci ynag digunakan sebagai berikut (1) Kategori sangat baik (SB) meliputi sangat mudah dipahami, sangat sesuai dan bermanfaat diberi nilai 4. (2) Kategori baik (B), mudah dipahami, jelas, menarik, sesuai dan bermanfaat diberi nilai 3. (3) Kategori kurang baik (KB) meliputi; kurang mudah dipahami, kurang jelas, kurang menarik, sesuai dan bermanfaat diberi nilai 2. (4) Kategori tidak bermanfaat diberi nilai 1.dak baik (TB) meliputi; tidak mudah dipahami, tidak jelas, tidak sesuai, tidak bermanfaat diberi nilai 1. Apabila telah dilakukan penilaian, maka skor yang diperoleh dihitung dengan menggunakan rumus (Arikunto, 2011).

$$
\begin{aligned}
& \quad N=\frac{\sum x}{\sum m a k s} \times 100 \\
& \text { Keterangan : } \\
& \mathrm{N} \quad=\text { nilai } \\
& \sum \mathrm{x} \quad=\text { jumlah skor yang diperoleh } \\
& \sum \mathrm{xmaks}=\text { jumlah skor maksimal }
\end{aligned}
$$

Apabila sudah diperoleh nilai dari masing-masing penilai, akan selanjutnya akan dihitung rata-rata dengan menggunakan rumus (Arikunto, 2011) yaitu:

$$
X=\frac{\sum x}{N}
$$

$$
\begin{aligned}
& \text { Keterangan : } \\
& \mathrm{X}=\text { Rata-rata nilai } \\
& \Sigma \mathrm{X}=\text { Jumlah nilai } \\
& \mathrm{N}=\text { Jumlah penilai }
\end{aligned}
$$

Sesudah diperoleh nilai kemudian, peneliti mempresentasekan kedalam kriteria penilaian kelayakan, yaitu sangat baik, baik, kurang baik, tidak baik menurut (Sugiyono, 2015).

Tabel 2. Kriteria Kelayakan

\begin{tabular}{ll}
$75 \%-100 \%$ & Sangat layak \\
\hline $50 \%-75 \%$ & Layak \\
\hline $25 \%-50 \%$ & Cukup layak \\
\hline $0 \%-25 \%$ & Kurang layak
\end{tabular}

\section{HASIL DAN PEMBAHASAN}

Hasil penelitian media pembelajaran komik IPA oleh dosen ahli, guru dan siswa melalui uji coba produk (kelompok kecil) dan uji coba produk (kelompok besar) adalah sebagai berikut: 


\section{Analisis Data Kualitatif Media Komik IPA}

a. Analisis Ahli Media

Penilaian media Komik IPA berbasis karakter peduli lingkungan dari sisi media dilakukan oleh Bapak M. Ragil Kurniawan, M.Pd yang merupakan salah satu dosen Pendidikan Guru Sekolah Dasar (PGSD) yang berkompeten di bidang teknologi pendidikan. Berikut ini merupakan hasil penilaian media terhadap kualitas Komik IPA berbasis karakter peduli lingkungan pada hari Rabu tanggal 23 Agustus 2017. Berdasarkan tabel 12 bahwa penilaian menunjukan jumlah skor 60 sehingga mendapat nilai 83,3 dan mendapat penilaian dengan kategori "Sangat Layak". Dengan rincian sebagai berikut :

1) Covernya diperbaharui dan perlu dimunculkan mata pelajaran yang jelas

2) Pada pengenalan tokoh ada satu tokoh yang belum diberi nama

3) Pada halaman 5 ditambahi gambar tokoh Udin agar jelas

4) Pada halaman 11-12 tambahkan materi tentang kambium agar frame komik tidak kosong dan isinya nyambung

5) Halaman 12 ditambahkan gambar tokoh Ibu Yati

\section{b. Analisis Penguji Ahli Materi}

Penilaian media Komik IPA berbasis karakter peduli lingkungan dari sisi ahli materi yang dilakukan oleh Ibu Siwi Purwanti, M.Pd pada tanggal 24 Agustus 2017 merupakan salah satu dosen Pendidikan Guru Sekolah Dasar (PGSD) yang berkompeten di bidang pendidikan IPA. Berikut hasil penilaian terhadap kualitas media Komik IPA berbasis karakter peduli lingkungan. Berdasarkan tabel 13 bahwa penilaian menunjukan jumlah skor 42 sehingga mendapat penilaian 87,5 dengan kategori "sangat layak". Media komik IPA berbasis karakter peduli lingkungan mendapatkan saran oleh ahli materi sebagai berikut :

1) Pada halaman 9 di pisah-pisah setiap fungsi akarnya, akan lebih menarik bila di buat balon kata.

2) Terdapat kesalahan penulisan pada halaman 14 sehingga perlu dilakukan pembenahan kata agar mudah di pahami.

3) Daftar pustakanya dibenahi kembali, sesuaikan dengan tata cara penulisan daftar pustaka yang baik dan benar.

\section{c. Analisis Penguji Ahli Pembelajaran}

Penialaian media Komik IPA berbasis karakter peduli lingkungan dari sisi ahli pembelajaran yang dilakukan oleh Panji Hidayat, M.Pd pada tanggal 24 Agustus 2017 merupakan salah satu dosen yang berkompeten di bidangnya. Berikut hasil penilaian terhadap kualitas media komik berbasis karakter peduli lingkungan. Berdasarkan tabel 14 bahwa penilaian menunjukan jumlah skor 46 sehingga mendapat penilaian 95,8 dengan kategori "sangat layak". Media komik IPA mendapatkan saran dari ahli pembelajaran yaitu latihan solanya dihapus karena komik tidak menggunakan latihan soal.

\section{d. Analisis Uji Coba Produk (Kelompok Kecil)}

Uji coba produk dilakukan di SD Muhammadiyah Kleco Kotagede Yogyakarta dengan jumlah 5 orang siswa. Guru dan siswa memberikan penilaian, masukan, dan saran. Berikut komentar dan saran dari siswa :

1) "Dapat dipahami, bagus tampilanya dan senang untuk dibaca" berdasarkan komentar dan saran yang ditulis siswa berarti media Komik IPA dapat dipahami dan dan di senangi oleh siswa.

2) "Komik IPA menarik dan mudah dipelajari" berdasarkan komentar yang ditulis siswa berarti media Komik IPA menarik dan mudah digunakan oleh siswa. 
3) "Saya sangat suka komik pengetahuan apalagi komik IPA, wah keren" berdasarkan komentar siswa berarti media Komik IPA sangat disukai oleh siswa.

4) Kometar dan saran dari guru: Media yang digunakan bagus, sesuai dengan kurikulum yang baru dengan berbasis karakter. Siswa dapat belajar sambil membaca komik dengan isi yang sangat menarik dan disukai oleh siswa.

e. Analisis Uji Coba Produk (Kelompok Besar)

Uji coba produk dilakukan di SD Muhammadiyah Kleco Kotagede Yogyakarta dengan jumlah 15 orang siswa. Dalam uji coba guru dan siswa memberikan penilaian dan komentar sebagai berikut:

1) "Komik IPA sangat bagus, mudah dibawa kemana-mana, menarik dan mudah dipahami dengan cepat" berdasarkan komentar tersebut diketahui bahwa siswa tertarik dengan komik IPA.

2) "Saya suka sekali komik sains karena bisa menambah pengetahuan" berdasarkan komentar tersebut diketahui bahwa siswa menyukai Komik IPA.

3) "Komik IPA menarik dan mudah dipelajari” berdasarkan komentar tersebut diketahui bahwa tertarik menggunakan media Komik IPA.

4) "Saya suka sekali komiknya, bagus sekali" berdasarkan komentar tersebut diketahui bahwa siswa suka menggunakan Komik IPA.

5) "Komik sains ini sangat bagus, lengkap dan banyak pelajaranya" berdasarkan komentar tersebut diketahui bahwa siswa tertarik dengan Komik IPA.

6) "Komik sains sangat bagus, menarik warnanya, ceritanya dan ada karakter peduli lingkunganya" berdasarkan komentar tersebut diketahui bahwa siswa sangat tertarik dengan Komik IPA.

7) Komentar dan saran dari guru: Media Komik IPA sudah bagus dan layak digunakan di dalam pembelajaran.

\section{Analisis Data Kuantitatif Komik IPA Berbasis Karakter Peduli Lingkungan Materi Struktur Dan Fungsi Bagian Tumbuhan}

Analisis data kuantitatif dilakukan untuk mengelola data yang diperoleh dari hasil penilaian ahl materi, ahli media, penilaian guru, dan angket penilaian siswa. Hasil data kuantitatif media Komik IPA berbasis karakter peduli lingkungan dari penilaian ahli media, ahli materi, uji coba produk (kelompok kecil), dan uji coba produk (kelompok besar) dapat diketahui rata-rata penilaian sebagai berikut:

$$
\mathrm{x}=\frac{\sum x}{N}
$$

\section{Keterangan :}

$$
\begin{array}{ll}
\mathrm{X} & =\text { Rata-Rata Nilai } \\
\Sigma & =\text { Jumlah Nilai } \\
\mathrm{N} & =\text { Jumlah Penilai }
\end{array}
$$

Berikut penjelasan untuk uji coba produk pada tabel sebagai berikut:

8)

Tabel 3. Hasil Penilaian Uji Coba Produk

\begin{tabular}{lllll} 
No & Penilaian & Skor & Nilai & Kategori \\
\hline 1 & Ahli Media & 60 & 83,3 & Sangat Layak \\
\hline 2 & Ahli Materi & 42 & 87,5 & Sangat Layak \\
\hline & Ahli & & & \\
3 & Pembelajaran & 46 & 98,5 & Sangat Layak
\end{tabular}


4 Uji coba kelompok kecil

\begin{tabular}{|c|c|c|c|}
\hline Siswa & 480 & 96 & Sangat Layak \\
\hline Guru & 47 & 97,9 & Sangat Layak \\
\hline \multicolumn{4}{|c|}{5 Uji coba kelompok besar } \\
\hline Siswa & 1.370 & 91,3 & Sangat Layak \\
\hline Guru & 47 & 97,9 & Sangat Layak \\
\hline Jumlah & \multicolumn{3}{|c|}{652,4} \\
\hline Rata-Rata & \multicolumn{3}{|c|}{93,2} \\
\hline Kategori & \multicolumn{3}{|c|}{ Sangat layak } \\
\hline
\end{tabular}

Gambar 1. Diagram Penilaian Produk kelompok kecil

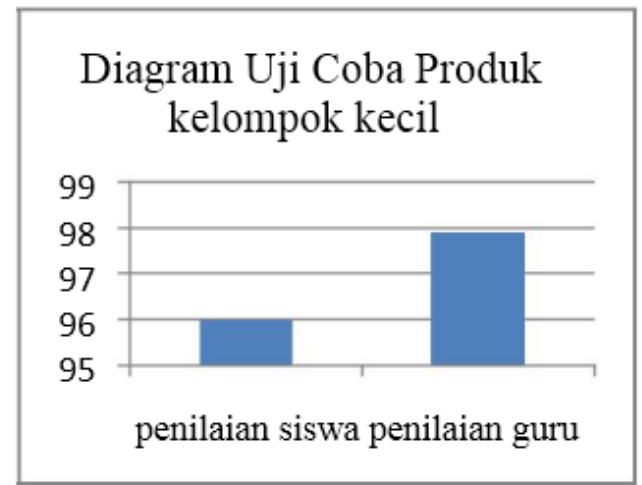

Gambar 2. Diagram Penilaian Ahli

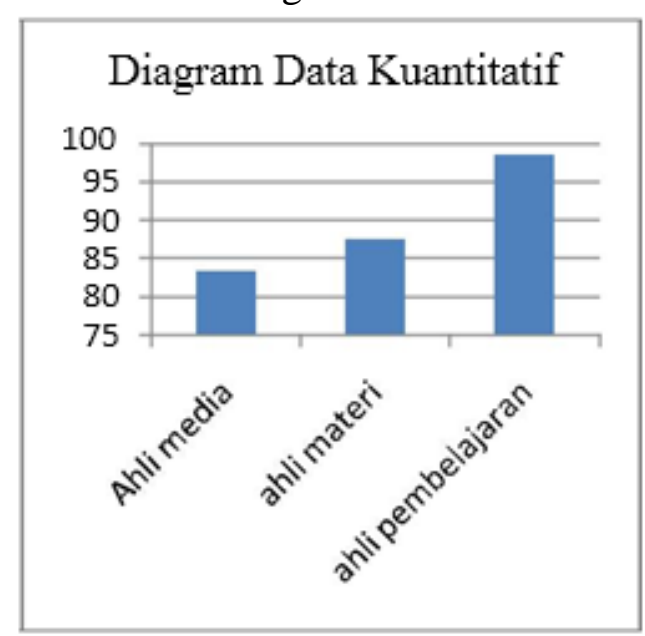

Gambar 3. Diagram Penilaian Produk Kelompok Besar 


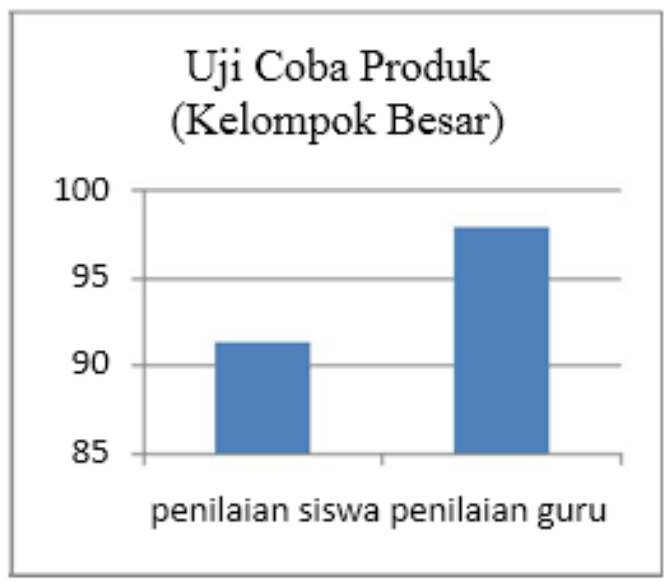

\section{SIMPULAN}

Pengembangan Komik IPA berbasis karakter peduli lingkungan kelas IV SD mengacu pada pengembangan Robert Maribe Brance yaitu ADDIE, Analisis, Design, Development, Implementation, and Evaluation. Komik IPA telah dinilai dari beberapa aspek yaitu materi, media dan pembelajaran. Kelayakan media pembelajaran komik IPA telah dikembangkan memperoleh hasil dari berbagai segi penilaian yaitu, penilaian ahli media, terhadap kualitas komik IPA memperoleh jumlah skor 60 dengan nilai 83,3 termasuk dalam kategori "sangat layak", Penilaian ahli materi, terhadap kualitas komik IPA memperoleh jumlah skor 42 dengan nilai 87,5 termasuk dalam kategori "sangat layak", Penilaian ahli pembelajaran, terhadp kualitas komik IPA memperoleh jumlah skor 46 dengan nilai 98,5 termasuk dalam kategori "sangat layak", Penilaian saat uji coba produk (kelompok kecil), angket penilaian terhadap Komik IPA memperoleh jumlah skor 480 dengan nilai 96 termasuk dalam kategori "sangat layak". Sedangkan penilaian guru terhadap kualitas Komik IPA mendapatkan jumlah skor 47 dengan nilai 97,9 termasuk dalam kategori "sangat layak". Penilaian uji coba produk (kelompok besar), angket penilaian terhadap komik IPA memperoleh jumlah skor 1.370 dengan nilai 91,3 termasuk dalam kategori "sangat layak". Sedangkan penilaian guru terhadap kualitas Komik IPA mendapatkan skor 47 dengan nilai 97,9 termasuk dalam kategori "sangat layak".

\section{DAFTAR PUSTAKA}

Arikunto, S. 2011. Dasar-Dasar Evaluasi Program Pendidikan. Jakarta: Bumi Aksara.

S. 2011. Prosedur Penelitian. Jakarta: Rineka Cipta.

Aunillah, N. I. 2011. Panduan Menerapkan Pendidikan Karakter Di Sekolah. Yogyakarta: Laksana.

Budiningsih, A. C. 2012. Belajar Dan Pembelajaran. Jakarta: Rineka Cipta.

Daryanto. 2012. Media Pembelajaran. Bandung: PT. Sarana Tutorial Nurani Sejahtera.

Hamalik, O. 2013. Proses Belajar Mengajar. Jakarta: Rosdakarya.

Juhartutik. 2011. Menjadi Guru Matematika Kreatif dan Berwawasan Pendidikan Karakter. Kreano, 13-16. 
Martani, N. T.Peningkatan Sikap Peduli Lingkungan Anak Prasekolah Melalui Bermain Peran "Aku Sayang Bumiku". Jurnal Psikologi Indonesia, 42. 2011.

Marzuki. Pengintegrasian Pendidikan Karajkter dalam Pembelajaran di Sekolah. Jurnal Pendidikan Karakter, 33-34. 2011.

Mulyasa. 2012. Kurikulum Tingkat Satuan Pendidikan. Bandung: PT Remaja Rosdakarya.

Riva'i, N. S. 2002. Media Pengajaran. Bandung: Sinar Baru Algensindo.

Salim, E. 2012. 40 Tahun Gerakan Lingkungan. Uni Sosial Demokrat, 2.

Sugiyono. 2015. Metode Penelitian \& Pengembangan Reasearch and Developmen. Bandung: Alfabeta. Alfabeta.

2015. Metode Penelitian Kuantitatif Kualitatif dan $R$ and D. Bandung:

Wisudawati, E. S. 2014. Metodologi Pembelajaran IPA. Jakarta: Bumi Aksara. 